$\begin{array}{cc}\text { ACADEMIA ROMÂNĂ } & \text { Rev. Roum. Chim., } \\ \text { 2019, 64(9), 817-828 }\end{array}$

\title{
SYNTHESIS OF IRON(III) OXIDE NANOPARTICLES VIA SIMPLE AND CHEAP PROCEDURES FOR ADSORPTION OF ENVIRONMENTALLY HARMFUL TOXIC HEAVY METALS
}

\author{
Ahmed ALHADHRAMI, ${ }^{a}$ Abdel Majid A. ADAM, ${ }^{a}$ \\ Abdulraheem S. A. ALMALKI, ${ }^{a}$ and Moamen S. REFAT ${ }^{\mathrm{a}, \mathrm{b},{ }^{*}}$

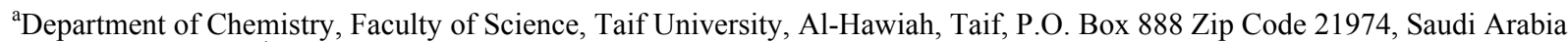 \\ ${ }^{\mathrm{b}}$ Department of Chemistry, Faculty of Science, Port Said University, Port Said, Egypt
}

Received March 23, 2019

\begin{abstract}
In aqueous media at $\sim 50{ }^{\circ} \mathrm{C}$, two new iron(III) complexes, $\left[\mathrm{Fe}_{3}\left(\mu-\mathrm{CO}_{3}\right)\left(\mathrm{NH}_{3}\right)(\mu-\mathrm{OH})_{2}\left(\mathrm{H}_{2} \mathrm{O}\right)_{5}\right.$ $\left.\left(\mu-\mathrm{H}_{2} \mathrm{O}\right)(\mathrm{OH})_{4}\right] \mathrm{Cl} \cdot 6 \mathrm{H}_{2} \mathrm{O}$ and $\left[\mathrm{Fe}_{3}\left(\mu-\mathrm{CO}_{3}\right)\left(\mathrm{NH}_{3}\right)(\mu-\mathrm{OH})_{2}\left(\mathrm{H}_{2} \mathrm{O}\right)_{5}\left(\mu-\mathrm{H}_{2} \mathrm{O}\right)(\mathrm{OH})_{4}\right] \mathrm{NO}_{3} \cdot 6 \mathrm{H}_{2} \mathrm{O}$, were synthesized from $\mathrm{FeCl}_{3} \cdot 6 \mathrm{H}_{2} \mathrm{O}$ and $\mathrm{Fe}\left(\mathrm{NO}_{3}\right)_{3} \cdot 9 \mathrm{H}_{2} \mathrm{O}$ with urea, a simple organic compound. These complexes were used as the primary precursors for iron(III) oxide $\left(\mathrm{Fe}_{2} \mathrm{O}_{3}\right)$ nanoparticle (NP) preparation via a thermal decomposition route at a low temperature $\left(600{ }^{\circ} \mathrm{C}\right)$ in a static air atmosphere. The complexes of iron(III) were analyzed through FTIR spectroscopy, thermal properties, conductivity and magnetic moment measurements, while the oxide materials were characterized through UV-Vis, XRD and SEM measurements. The study also aimed to investigate the performance and capacity of $\mathrm{Fe}_{2} \mathrm{O}_{3}$ NPs for the removal of some heavy metals, such as cadmium $\left(\mathrm{Cd}^{2+}\right)$, lead $\left(\mathrm{Pb}^{2+}\right)$, and mercury $\left(\mathrm{Hg}^{2+}\right)$ ions. The optimum adsorbent dose, contact time, and $\mathrm{pH}$ values for maximum $\mathrm{Cd}^{2+}, \mathrm{Pb}^{2+}$ and $\mathrm{Hg}^{2+}$ metal ion removal were identified. The adsorption behavior was found to be highly pH-dependent, and the $\mathrm{Fe}_{2} \mathrm{O}_{3}$ NPs selectively absorbed $\mathrm{Cd}^{2+}, \mathrm{Pb}^{2+}$ and $\mathrm{Hg}^{2+}$ metal ions from wastewater.
\end{abstract}

\section{INTRODUCTION}

Industrial development has led to an increase in pollution, including increased heavy metal release into the environment, which represents a serious global environmental problem. ${ }^{1}$ Activated carbon is often used as an adsorbent in order to remove heavy metals from waste streams. Despite the widespread use of activated carbon to treat sewage and water, activated carbon remains an expensive option., ${ }^{2,3}$ Recently, commercially available, low-cost alternatives to activated carbon have become available, and their use and ability to remove heavy metals must be evaluated. Metal oxides have important applications in several fields, such as materials science, physics, and chemistry, ${ }^{4-10}$ and these oxides are used to manufacture precision circuits, catalysts, anticorrosion coatings, sensors, and fuel cells. In order to control environmental pollution, substances containing oxides are used to remove carbon dioxide and the nitrogen and sulfur oxides that are emitted during the combustion of fossil fuels. ${ }^{11}$ Furthermore, metal oxides are used to manufacture the different types of semiconductors that are used in computer chips. ${ }^{12}$ Currently, inorganic scientists are exploring new uses and applications for metal oxide materials. ${ }^{13-15}$ Iron (III) oxide $\left(\mathrm{Fe}_{2} \mathrm{O}_{3}\right)$ nanoparticles (NPs) have large surface areas and can be easily linked with various chemicals. ${ }^{16-18}$ These properties facilitate their use in several promising applications, such as environmental treatments and the development of magnetic recording devices, sensors, electronic devices, and catalysts.

\footnotetext{
*Corresponding author: msrefat@yahoo.com
} 


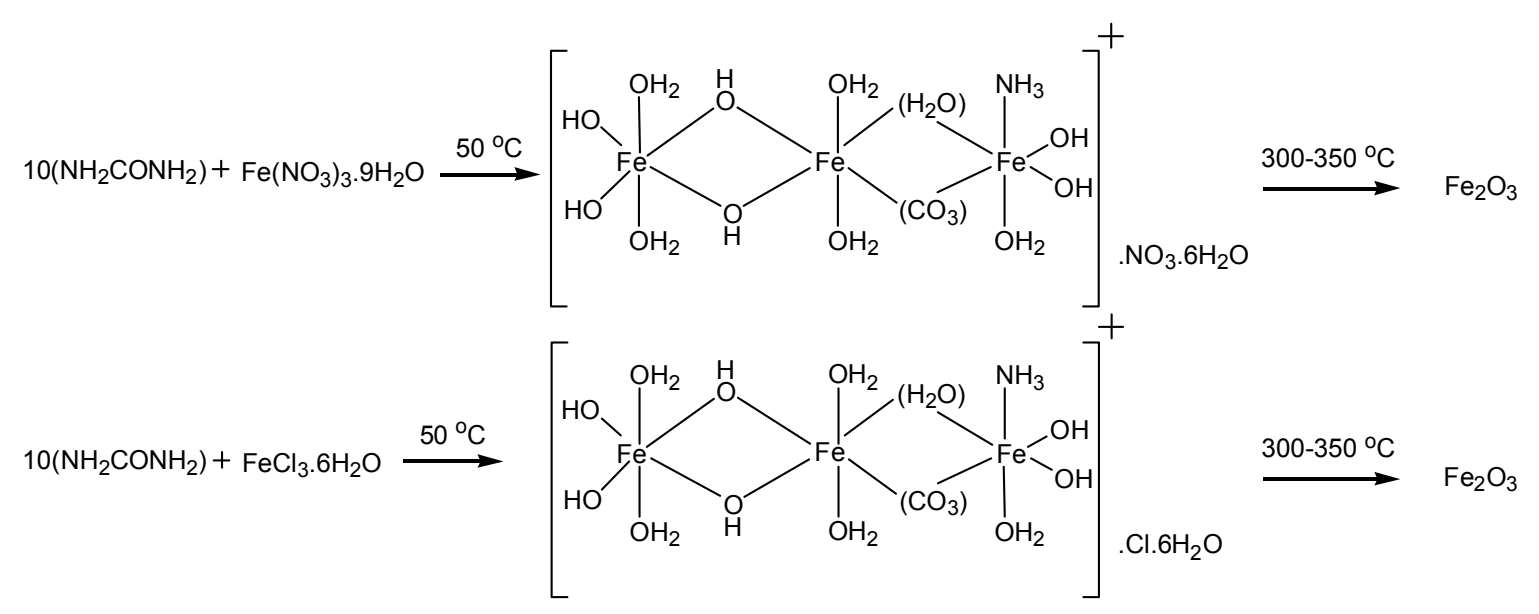

Scheme 1 - Preparations of the iron(III) complexes and $\mathrm{Fe}_{2} \mathrm{O}_{3}$ product.

Several studies have reported $\mathrm{Fe}_{2} \mathrm{O}_{3}$ synthesis and characterization in the presence of urea. For examples, Ocana et al. ${ }^{19}$ described a method for $\mathrm{Fe}_{2} \mathrm{O}_{3}$ particle preparation by precipitation from aqueous solutions of $\mathrm{FeCl}_{3}, \mathrm{Fe}\left(\mathrm{ClO}_{4}\right)_{3}$, and $\mathrm{Fe}\left(\mathrm{NO}_{3}\right)_{3}$ at $100{ }^{\circ} \mathrm{C}$ in the presence of urea. Bakardjieva et al. ${ }^{20}$ prepared uniform spherical hydrous $\mathrm{Fe}_{2} \mathrm{O}_{3}$ particles through urea decomposition of the homogeneous precipitation of $\mathrm{Fe}_{2}\left(\mathrm{SO}_{4}\right)_{3}$. Asuha et al. ${ }^{21,22}$ developed a new method for the preparation of $\mathrm{Fe}_{2} \mathrm{O}_{3}$ nanopowder via thermal decomposition of the $\left.\left[\mathrm{FeCON}_{2} \mathrm{H}_{4}\right)_{6}\right]\left(\mathrm{NO}_{3}\right)_{3}$ complex, and they studied the effects of synthetic routes of this complex on the resulting $\mathrm{Fe}_{2} \mathrm{O}_{3}$ nanopower. ${ }^{23}$ Jović et al. ${ }^{24}$ prepared $\mathrm{Fe}_{2} \mathrm{O}_{3} \mathrm{NPs}$ via hydrolysis of $\mathrm{Fe}\left(\mathrm{NO}_{3}\right)_{3}$ in the presence of urea and oleic acid. Liang et al $^{25}$ described an easy, simple, and economical method for preparation of $\mathrm{Fe}_{2} \mathrm{O}_{3}$ microflowers via an urea-assisted hydrothermal synthetic route. They used the $\mathrm{Fe}_{2} \mathrm{O}_{3}$ product as an adsorbent for water treatment with a potential adsorbent capacity for As (V) and $\mathrm{Cr}(\mathrm{VI})$ heavy metal ion removal. $\mathrm{Fe}_{2} \mathrm{O}_{3}$ is reported to remove lead $(\mathrm{Pb}),{ }^{26}$ arsenic (As) ${ }^{27}$ and mercury $(\mathrm{Hg})^{28}$ from water. Wang et al. ${ }^{29}$ used $\mathrm{FeCl}_{3}$ to prepare $\mathrm{Fe}_{2} \mathrm{O}_{3}$ and $\mathrm{Fe}_{3} \mathrm{O}_{4}$ nanostructures with different morphologies via an ethylene glycol (EG)mediated process with the assistance of urea and cetyl trimethyl ammonium bromide (CTAB). They used these oxides to adsorb $\mathrm{Cr}(\mathrm{VI})$ ions with a maximum adsorption capacity equal to $6.9 \mathrm{mgg}^{-1}$. This value was higher than that of commercial bulk $\mathrm{Fe}_{2} \mathrm{O}_{3}$. In this study, we aimed to prepare two new proposed iron (III) complexes from the reaction of $\mathrm{FeCl}_{3} \cdot 6 \mathrm{H}_{2} \mathrm{O}$ and $\mathrm{Fe}\left(\mathrm{NO}_{3}\right)_{3} \cdot 9 \mathrm{H}_{2} \mathrm{O}$ salts with urea at $\sim 50{ }^{\circ} \mathrm{C}$. These proposed complexes were $\left[\mathrm{Fe}_{3}\left(\mu-\mathrm{CO}_{3}\right)\left(\mathrm{NH}_{3}\right)(\mu-\mathrm{OH})_{2}\left(\mathrm{H}_{2} \mathrm{O}\right)_{5}\left(\mu-\mathrm{H}_{2} \mathrm{O}\right)(\mathrm{OH})_{4}\right]$ $\mathrm{Cl} \cdot 6 \mathrm{H}_{2} \mathrm{O}$ and $\left[\mathrm{Fe}_{3}\left(\mu-\mathrm{CO}_{3}\right)\left(\mathrm{NH}_{3}\right)(\mu-\mathrm{OH})_{2}\left(\mathrm{H}_{2} \mathrm{O}\right)_{5}(\mu-\right.$ $\left.\left.\mathrm{H}_{2} \mathrm{O}\right)(\mathrm{OH})_{4}\right] \mathrm{NO}_{3} \cdot 6 \mathrm{H}_{2} \mathrm{O}$, which were thermally decomposed at $600{ }^{\circ} \mathrm{C}$ in air atmosphere to produce $\mathrm{Fe}_{2} \mathrm{O}_{3}$ NPs. The capability of the resulting $\mathrm{Fe}_{2} \mathrm{O}_{3}$ to purify water contaminated with heavy elements resulting from industrial waste, such as $\mathrm{Cd}, \mathrm{Pb}$, and $\mathrm{Hg}$ was investigated.

\section{EXPERIMENTAL}

\section{General}

Urea and metal salts, $\mathrm{FeCl}_{3} \cdot 6 \mathrm{H}_{2} \mathrm{O}, \mathrm{Fe}\left(\mathrm{NO}_{3}\right)_{3} \cdot 9 \mathrm{H}_{2} \mathrm{O}$, $\mathrm{Cd}\left(\mathrm{NO}_{3}\right)_{2}, \mathrm{~Pb}\left(\mathrm{CH}_{3} \mathrm{COO}\right)_{2}$, and $\mathrm{Hg}\left(\mathrm{NO}_{3}\right)_{2}$, were received from Sigma-Aldrich and used as obtained. The solvents were spectroscopic grade. Elemental analyses of $\% \mathrm{~N}, \% \mathrm{H}$, and $\% \mathrm{C}$ were performed using a Perkin Elmer CHN 2400 instrument. The iron metal content was obtained using an atomic absorption spectrometer model PYE-UNICAM SP 1900. The molar conductivity of the iron(III) complexes with a $10^{-3} \mathrm{~mol} / \mathrm{cm}^{3}$ concentration were obtained with a Jenway 4010 conductivity meter. A UV2-Unicam UV/Vis spectrophotometer was used to record the electronic absorption of the $\mathrm{Fe}_{2} \mathrm{O}_{3}$ NPs $(200-800 \mathrm{~nm})$. A Sherwood Scientific model instrument was used to measure the magnetic susceptibilities of the samples at room temperature via the Gouy method [30]. The IR spectra ( $\mathrm{KBr}$ discs) were obtained on a Bruker FT-IR spectrophotometer within the range 400$4000 \mathrm{~cm}^{-1}$. Thermogravimetric (TG) curves were obtained using a Shimadzu computerized thermal analysis system (TGA-50H). The XRD patterns were collected on an X Pert Philips X-ray diffractometer. The SEM micrographs were visualized using a Jeol Jem-1200 EX II Electron microscope $(25 \mathrm{kV})$.

\section{Synthesis}

The two new proposed iron (III) complexes, $\left[\mathrm{Fe}_{3}(\mu\right.$ $\left.\left.\mathrm{CO}_{3}\right)\left(\mathrm{NH}_{3}\right)(\mu-\mathrm{OH})_{2}\left(\mathrm{H}_{2} \mathrm{O}\right)_{5}\left(\mu-\mathrm{H}_{2} \mathrm{O}\right)(\mathrm{OH})_{4}\right] \mathrm{Cl} \cdot 6 \mathrm{H}_{2} \mathrm{O}$ and $\left[\mathrm{Fe}_{3}(\mu-\right.$ $\left.\left.\mathrm{CO}_{3}\right)\left(\mathrm{NH}_{3}\right)(\mu-\mathrm{OH})_{2}\left(\mathrm{H}_{2} \mathrm{O}\right)_{5}\left(\mu-\mathrm{H}_{2} \mathrm{O}\right)(\mathrm{OH})_{4}\right] \mathrm{NO}_{3} \cdot 6 \mathrm{H}_{2} \mathrm{O}$ were prepared by mixing equal volumes $(100 \mathrm{~mL})$ of $\mathrm{FeCl}_{3} \cdot 6 \mathrm{H}_{2} \mathrm{O}$ or $\mathrm{Fe}\left(\mathrm{NO}_{3}\right)_{3} \cdot 9 \mathrm{H}_{2} \mathrm{O}(0.01 \mathrm{~mol})$ with urea $(0.1 \mathrm{~mol})$ at $50{ }^{\circ} \mathrm{C}$, respectively. These complexes began to settle as a brown precipitate after a long heating time of approximately 16 hours. After separation by filtration, the precipitates were washed several times with hot water to remove all urea residue and then dried in a vacuum dissector over $\mathrm{P}_{2} \mathrm{O}_{5}$ for approximately four days. 
$\left[\mathrm{Fe}_{3}\left(\mu-\mathrm{CO}_{3}\right)\left(\mathrm{NH}_{3}\right)(\mu-\mathrm{OH})_{2}\left(\mathrm{H}_{2} \mathrm{O}\right)_{5}\left(\mu-\mathrm{H}_{2} \mathrm{O}\right)(\mathrm{OH})_{4}\right] \mathrm{Cl} \cdot 6 \mathrm{H}_{2} \mathrm{O}$; complex 1: yield $73 \%$. M.p. $>250{ }^{\circ}$ C. Anal.: (Calc.) Found, \%: C, (2.01) 1.99; H; (5.52) 5.50; N, (2.34) 2.30; Fe, (28.02) 27.98. $\Lambda_{\mathrm{M}}=71 \Omega^{-1} \cdot \mathrm{cm}^{2} \cdot \mathrm{mol}^{-1}$.

$\left[\mathrm{Fe}_{3}\left(\mu-\mathrm{CO}_{3}\right)\left(\mathrm{NH}_{3}\right)(\mu-\mathrm{OH})_{2}\left(\mathrm{H}_{2} \mathrm{O}\right)_{5}\left(\mu-\mathrm{H}_{2} \mathrm{O}\right)(\mathrm{OH})_{4}\right] \mathrm{NO}_{3} \cdot 6 \mathrm{H}_{2} \mathrm{O}$ complex 2: yield $76 \%$. M.p. $>250{ }^{\circ} \mathrm{C}$. Anal.: (Calc.) Found, \%: C, (1.92) 1.89; H; (5.28) 5.25; N, (4.48) 4.42; Fe, (26.83) 26.76. $\Lambda_{\mathrm{M}}=64 \Omega^{-1} \cdot \mathrm{cm}^{2} \cdot \mathrm{mol}^{-1}$.

The $\mathrm{Fe}_{2} \mathrm{O}_{3}$ NPs were prepared by the thermal decomposition of the iron(III) complexes at $600{ }^{\circ} \mathrm{C}$ in an air oxygen atmosphere.

\section{Adsorption experiments}

The adsorption experiments were performed in $50 \mathrm{~mL}$ glass bottles using $50 \mathrm{mg}$ of the $\mathrm{Fe}_{2} \mathrm{O}_{3}$ product as the adsorbent in $30 \mathrm{~mL}$ of stock aqueous solutions of $\mathrm{Cd}^{2+}, \mathrm{Pb}^{2+}$ and $\mathrm{Hg}^{2+}$ ions. The stock solutions of $\mathrm{Cd}^{2+}, \mathrm{Pb}^{2+}$ and $\mathrm{Hg}^{2+}$ were prepared by dissolving a suitable amount $(20 \mathrm{mg})$ of $\mathrm{Cd}\left(\mathrm{NO}_{3}\right)_{2}, \mathrm{~Pb}\left(\mathrm{CH}_{3} \mathrm{COO}\right)_{2}$ or $\mathrm{Hg}\left(\mathrm{NO}_{3}\right)_{2}$ in $100 \mathrm{~mL}$ deionized water. The contents in each glass bottle were shaken for different times $(10,20,30,40,50$ or 60 minutes). After each mixing time, the $\mathrm{Fe}_{2} \mathrm{O}_{3}$ were anchored on the bottom of the bottle, and the residue was removed by filtration. Atomic absorption spectroscopy was used to determine the concentration of the unabsorbed heavy metal ions in the supernatant liquid. The $\mathrm{pH}$ of the solutions was adjusted using sodium hydroxide $(0.01 \mathrm{~N})$ or hydrochloric acid $(0.01 \mathrm{~N})$.

\section{RESULTS AND DISCUSSION}

\section{Preface}

The two new brown solid complexes, $\left[\mathrm{Fe}_{3}(\mu-\right.$ $\left.\left.\mathrm{CO}_{3}\right)\left(\mathrm{NH}_{3}\right)(\mu-\mathrm{OH})_{2}\left(\mathrm{H}_{2} \mathrm{O}\right)_{5}\left(\mu-\mathrm{H}_{2} \mathrm{O}\right)(\mathrm{OH})_{4}\right] \mathrm{Cl} \cdot 6 \mathrm{H}_{2} \mathrm{O}$ and $\quad\left[\mathrm{Fe}_{3}\left(\mu-\mathrm{CO}_{3}\right)\left(\mathrm{NH}_{3}\right)(\mu-\mathrm{OH})_{2}\left(\mathrm{H}_{2} \mathrm{O}\right)_{5}(\mu-\right.$ $\left.\left.\mathrm{H}_{2} \mathrm{O}\right)(\mathrm{OH})_{4}\right] \mathrm{NO}_{3} \cdot 6 \mathrm{H}_{2} \mathrm{O}$ were obtained in aqueous solutions at a moderate temperature $\left(\sim 50{ }^{\circ} \mathrm{C}\right)$ via the reaction of urea with $\mathrm{FeCl}_{3} \cdot 6 \mathrm{H}_{2} \mathrm{O}$ and $\mathrm{Fe}\left(\mathrm{NO}_{3}\right)_{3} \cdot 9 \mathrm{H}_{2} \mathrm{O}$, respectively. These solid complexes were identified through their elemental analyses and infrared spectra. The thermal analyses (TG and DTG) of the two complexes were also used to establish their proposed structures. The $\mathrm{Fe}_{2} \mathrm{O}_{3} \quad \mathrm{NPs}$ were prepared by thermal decomposition of the iron(III) complexes at $600{ }^{\circ} \mathrm{C}$ in an oxygen atmosphere. The proposed structures of the iron(III) complexes before and after the thermal decomposition were investigated using spectroscopic and physical measurements. Scheme 1 shows the proposed route for the preparation of the iron (III) complexes and $\mathrm{Fe}_{2} \mathrm{O}_{3}$ product.

\section{FTIR study}

Table 1 gives the IR vibrational assignments of the $\quad\left[\mathrm{Fe}_{3}\left(\mu-\mathrm{CO}_{3}\right)\left(\mathrm{NH}_{3}\right)(\mu-\mathrm{OH})_{2}\left(\mathrm{H}_{2} \mathrm{O}\right)_{5}(\mu-\right.$ $\left.\left.\mathrm{H}_{2} \mathrm{O}\right)(\mathrm{OH})_{4}\right] \mathrm{Cl} \cdot 6 \mathrm{H}_{2} \mathrm{O}$ and $\left[\mathrm{Fe}_{3}\left(\mu-\mathrm{CO}_{3}\right)\left(\mathrm{NH}_{3}\right)(\mu-\right.$ $\left.\mathrm{OH})_{2}\left(\mathrm{H}_{2} \mathrm{O}\right)_{5}\left(\mu-\mathrm{H}_{2} \mathrm{O}\right)(\mathrm{OH})_{4}\right] \mathrm{NO}_{3} \cdot 6 \mathrm{H}_{2} \mathrm{O}$ complexes. The infrared spectra of the two iron(III) complexes have common features: (i) the bands due to the coordinated urea were absent; (ii) a number of bands observed at approximately 1387 and 1499 $\mathrm{cm}^{-1}$ were related to the bond vibrations of $\mathrm{v}(\mathrm{C}-\mathrm{O})$ in the $\mathrm{CO}_{3}$ group, and these bands were characteristic of the bridged carbonato ligand [31]; (iii) a set of bands attributed to the stretching vibrations of uncoordinated $\mathrm{H}_{2} \mathrm{O}$ molecules and bridged hydroxide ligands were observed in the region of $3452-3354 \mathrm{~cm}^{-1,31,32}$ (iv) the band observed at $3195-3202 \mathrm{~cm}^{-1}$ was associated with the stretching motion of the ammine group; $\mathrm{NH}_{3}{ }^{32}$

The IR spectrum of the $\left[\mathrm{Fe}_{3}\left(\mu-\mathrm{CO}_{3}\right)\left(\mathrm{NH}_{3}\right)(\mu-\right.$ $\left.\mathrm{OH})_{2}\left(\mathrm{H}_{2} \mathrm{O}\right)_{5}\left(\mu-\mathrm{H}_{2} \mathrm{O}\right)(\mathrm{OH})_{4}\right] \quad \mathrm{NO}_{3} \cdot 6 \mathrm{H}_{2} \mathrm{O} \quad$ complex shows a set of bands at 1387 and $829 \mathrm{~cm}^{-1}$ with strong-to-medium intensities, and they were characteristic of the ionic nitrate group; $\mathrm{NO}_{3}{ }^{-31,33}$ The IR spectra of both iron(III) complexes suggest the existence of the same cationic ion complex; $\left[\mathrm{Fe}_{3}\left(\mu-\mathrm{CO}_{3}\right)\left(\mathrm{NH}_{3}\right)(\mu-\mathrm{OH})_{2}\left(\mathrm{H}_{2} \mathrm{O}\right)_{5}\left(\mu-\mathrm{H}_{2} \mathrm{O}\right)(\mathrm{OH})_{4}\right]^{+}$, but the anionic counter ion differs, e.g., $\mathrm{NO}_{3}{ }^{-}$or $\mathrm{Cl}^{-}$, which agrees with the elemental analysis data. Heating of an aqueous mixture of $\mathrm{FeCl}_{3} \cdot 6 \mathrm{H}_{2} \mathrm{O}$ or $\mathrm{Fe}\left(\mathrm{NO}_{3}\right)_{3} \cdot 9 \mathrm{H}_{2} \mathrm{O}$ with urea formed the $\left[\mathrm{Fe}_{3}(\mu-\right.$ $\left.\left.\mathrm{CO}_{3}\right)\left(\mathrm{NH}_{3}\right)(\mu-\mathrm{OH})_{2}\left(\mathrm{H}_{2} \mathrm{O}\right)_{5}\left(\mu-\mathrm{H}_{2} \mathrm{O}\right)(\mathrm{OH})_{4}\right]^{+}$ion as follows: $\mathrm{Fe}^{3+}$ ions complexed with urea to form the parent complex [34] of the type $\left[\mathrm{Fe}(\text { urea })_{6}\right] \mathrm{X}_{3}$ (where $\mathrm{X}=\mathrm{Cl}^{-}$or $\mathrm{NO}_{3}^{-}$) at room temperature, but at moderate temperatures, the following reactions may occur:

$$
\begin{gathered}
3\left[\mathrm{Fe}\left(\mathrm{NH}_{2} \mathrm{CONH}_{2}\right)_{6}\right] \mathrm{Cl}_{3}+37 \mathrm{H}_{2} \mathrm{O} \rightarrow \\
{\left[\mathrm{Fe}_{3}\left(\mu-\mathrm{CO}_{3}\right)\left(\mathrm{NH}_{3}\right)(\mu-\mathrm{OH})_{2}\left(\mathrm{H}_{2} \mathrm{O}\right)_{5}\left(\mu-\mathrm{H}_{2} \mathrm{O}\right)(\mathrm{OH})_{4}\right] \mathrm{Cl} \cdot 6 \mathrm{H}_{2} \mathrm{O}+8 \mathrm{HCl}+35 \mathrm{NH}_{3}+17 \mathrm{CO}_{2}} \\
3\left[\mathrm{Fe}\left(\mathrm{NH}_{2} \mathrm{CONH}_{2}\right)_{6}\right]\left(\mathrm{NO}_{3}\right)_{3}+37 \mathrm{H}_{2} \mathrm{O} \rightarrow \\
{\left[\mathrm{Fe}_{3}\left(\mu-\mathrm{CO}_{3}\right)\left(\mathrm{NH}_{3}\right)(\mu-\mathrm{OH})_{2}\left(\mathrm{H}_{2} \mathrm{O}\right)_{5}\left(\mu-\mathrm{H}_{2} \mathrm{O}\right)(\mathrm{OH})_{4}\right] \mathrm{NO}_{3} \cdot 6 \mathrm{H}_{2} \mathrm{O}+8 \mathrm{HNO}_{3}+35 \mathrm{NH}_{3}+17 \mathrm{CO}_{2}}
\end{gathered}
$$


The bands associated with the bridged carbonato ligand in the two iron(III) complexes are assigned as follows. The symmetric $v_{\mathrm{s}}\left(\mathrm{CO}_{2}\right), v_{1}$, is observed at $1499 \mathrm{~cm}^{-1}$ for the two complexes, while the anti-symmetric $v_{\text {as }}\left(\mathrm{CO}_{2}\right), v_{4}$, is observed at $1387 \mathrm{~cm}^{-1}$ for the two complexes. The $v(\mathrm{C}-\mathrm{O})$, $\mathrm{v}_{2}$, vibration in the two complexes appears as one medium intensity band at $1031 \mathrm{~cm}^{-1}$. The $\delta\left(\mathrm{CO}_{2}\right)$ vibration in the two complexes appears as medium-weak intensity bands at 829 and $768 \mathrm{~cm}^{-1}$. The assignments of these bands agree well with those known for the related bridged carbonate complexes. ${ }^{31}$ The various $v(\mathrm{O}-\mathrm{H})$ vibrations of the uncoordinated water molecules and the bridged hydroxide ligand in the two complexes are clearly observed as a number of weak broad bands in the 3452-3354 $\mathrm{cm}^{-1}$ region, while the associated bending motions of the coordinated water molecules are located as expected at 1642 and $1635 \mathrm{~cm}^{-1}$. The bending vibration of the ammine group, $\delta\left(\mathrm{NH}_{3}\right)$, was assigned to the bands at 1567 and $\sim 1160 \mathrm{~cm}^{-1}$, while that of the $v\left(\mathrm{NH}_{3}\right)$ vibration was observed as a weak broad band in its characteristic place at $\sim 3200 \mathrm{~cm}^{-1}$.

\section{Thermal analysis study}

The TG and DTG analyses were performed for the $\quad\left[\mathrm{Fe}_{3}\left(\mu-\mathrm{CO}_{3}\right)\left(\mathrm{NH}_{3}\right)(\mu-\mathrm{OH})_{2}\left(\mathrm{H}_{2} \mathrm{O}\right)_{5}(\mu-\right.$ $\left.\left.\mathrm{H}_{2} \mathrm{O}\right)(\mathrm{OH})_{4}\right] \mathrm{Cl} \cdot 6 \mathrm{H}_{2} \mathrm{O}$ and $\left[\mathrm{Fe}_{3}\left(\mu-\mathrm{CO}_{3}\right)\left(\mathrm{NH}_{3}\right)(\mu-\right.$ $\left.\mathrm{OH})_{2}\left(\mathrm{H}_{2} \mathrm{O}\right)_{5}\left(\mu-\mathrm{H}_{2} \mathrm{O}\right)(\mathrm{OH})_{4}\right] \mathrm{NO}_{3} \cdot 6 \mathrm{H}_{2} \mathrm{O}$ complexes under an air atmosphere (Fig. 1). The $\left[\mathrm{Fe}_{3}(\mu-\right.$ $\left.\left.\mathrm{CO}_{3}\right)\left(\mathrm{NH}_{3}\right)(\mu-\mathrm{OH})_{2}\left(\mathrm{H}_{2} \mathrm{O}\right)_{5}\left(\mu-\mathrm{H}_{2} \mathrm{O}\right)(\mathrm{OH})_{4}\right] \mathrm{Cl} \cdot 6 \mathrm{H}_{2} \mathrm{O}$ complex thermally degraded in four steps. The first step occurs at $48{ }^{\circ} \mathrm{C}$, which represents the dehydration of four uncoordinated water molecules. The actual weight loss from this degradation step was $12.0 \%$, while the theoretical weight loss is $12.04 \%$. The second step of the decomposition occurs at a maximum temperature of $221{ }^{\circ} \mathrm{C}$. The IR spectrum (Fig. 2a,b) of the thermal product at this temperature clearly indicates the formation of the $\mathrm{NCO}^{-}$group with its characteristic $v(\mathrm{~N} \equiv \mathrm{C})$ at $\sim 2200 \mathrm{~cm}^{-1},{ }^{35}$ due to the combination of $\mathrm{NH}_{3}$ and $\mathrm{CO}_{3}$ at high temperatures. ${ }^{36}$ This important result strongly supports our conclusion concerning the proposed structures of these complexes under investigation. Nine uncoordinated water molecules were lost in the second step (found, 27.0\%; calc., 27.09\%). The third step occurs at a maximum temperature of $412{ }^{\circ} \mathrm{C}$. The weight loss in the third step is $15.0 \%$ due to the loss of $3 \mathrm{H}_{2} \mathrm{O}$ and $\mathrm{HCl}$, which is in agreement with the theoretical weight loss value of $15.13 \%$.

The last decomposition step occurs at $540{ }^{\circ} \mathrm{C}$ and is accompanied by a weight loss of $6.5 \%$, corresponding to the loss of $1 / 2 \mathrm{O}_{2}$ and $\mathrm{CN}$ molecules as a result of the degradation of the $\mathrm{NCO}$ group, to give $\mathrm{Fe}_{2} \mathrm{O}_{3}$. The loss of $\mathrm{H}_{2} \mathrm{O}$ molecules in the degradation steps indicates that $\mathrm{H}_{2} \mathrm{O}$ molecules with different lattice proposed structures exist in the complex. According to the above discussion, the decomposition mechanism of the $\quad\left[\mathrm{Fe}_{3}\left(\mu-\mathrm{CO}_{3}\right)\left(\mathrm{NH}_{3}\right)(\mu-\mathrm{OH})_{2}\left(\mathrm{H}_{2} \mathrm{O}\right)_{5}(\mu-\right.$ $\left.\left.\mathrm{H}_{2} \mathrm{O}\right)(\mathrm{OH})_{4}\right] \mathrm{Cl} \cdot 6 \mathrm{H}_{2} \mathrm{O}$ complex is as follows:

$$
\begin{gathered}
{\left[\mathrm{Fe}_{3}\left(\mu-\mathrm{CO}_{3}\right)\left(\mathrm{NH}_{3}\right)(\mu-\mathrm{OH})_{2}\left(\mathrm{H}_{2} \mathrm{O}\right)_{5}\left(\mu-\mathrm{H}_{2} \mathrm{O}\right)(\mathrm{OH})_{4}\right] \mathrm{Cl} \cdot 6 \mathrm{H}_{2} \mathrm{O} \stackrel{48^{\circ} \mathrm{C}}{\longrightarrow}} \\
{\left[\mathrm{Fe}_{3}\left(\mu-\mathrm{CO}_{3}\right)\left(\mathrm{NH}_{3}\right)(\mu-\mathrm{OH})_{2}\left(\mathrm{H}_{2} \mathrm{O}\right)_{5}\left(\mu-\mathrm{H}_{2} \mathrm{O}\right)(\mathrm{OH})_{4}\right] \mathrm{Cl} \cdot 2 \mathrm{H}_{2} \mathrm{O}+4 \mathrm{H}_{2} \mathrm{O}} \\
{\left[\mathrm{Fe}_{3}\left(\mu-\mathrm{CO}_{3}\right)\left(\mathrm{NH}_{3}\right)(\mu-\mathrm{OH})_{2}\left(\mathrm{H}_{2} \mathrm{O}\right)_{5}\left(\mu-\mathrm{H}_{2} \mathrm{O}\right)(\mathrm{OH})_{4}\right] \mathrm{Cl} \cdot 2 \mathrm{H}_{2} \mathrm{O}} \\
\stackrel{221^{\circ} \mathrm{C}}{\longrightarrow}\left[\mathrm{Fe}_{3}(\mathrm{NCO})(\mathrm{OH})_{7}\right] \cdot \mathrm{Cl}+9 \mathrm{H}_{2} \mathrm{O} \\
{\left[\mathrm{Fe}_{3}(\mathrm{NCO})(\mathrm{OH})_{7}\right] \cdot \mathrm{Cl}+9 \mathrm{H}_{2} \mathrm{O} \stackrel{412^{\circ} \mathrm{C}}{\longrightarrow}\left[\mathrm{Fe}_{3}(\mathrm{NCO})(\mathrm{O})_{4}\right]+3 \mathrm{H}_{2} \mathrm{O}+\mathrm{HCl}} \\
{\left[\mathrm{Fe}_{3}(\mathrm{NCO})(\mathrm{O})_{4}\right] \stackrel{421^{\circ} \mathrm{C}}{\longrightarrow}\left(\mathrm{Fe}_{2} \mathrm{O}_{3}\right)_{1.5}+1 / 2 \mathrm{O}+\mathrm{CN}}
\end{gathered}
$$

The IR spectrum of the final thermal degradation product for this complex supports the suggested mechanism. The IR spectrum shows the absence of the bands of uncoordinated water molecules and carbonate, ammine and hydroxyl groups and the presence of two strong bands of $\mathrm{Fe}_{2} \mathrm{O}_{3},{ }^{31}$ at 565 and $466 \mathrm{~cm}^{-1}$, which are related to $\mathrm{Fe}-\mathrm{O}$ bond vibrations. 

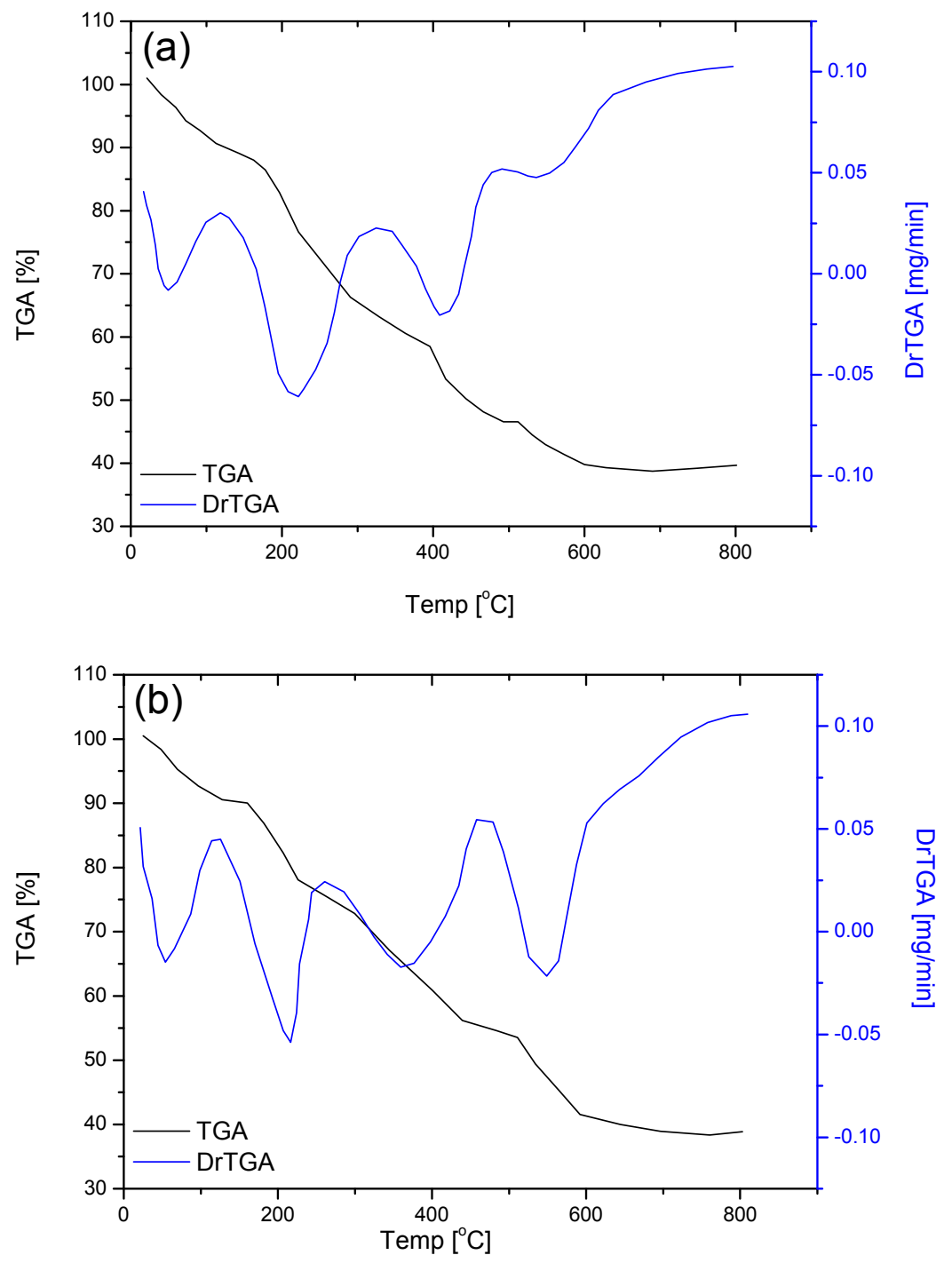

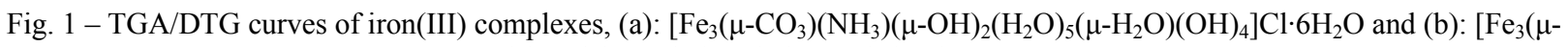
$\left.\left.\mathrm{CO}_{3}\right)\left(\mathrm{NH}_{3}\right)(\mu-\mathrm{OH})_{2}\left(\mathrm{H}_{2} \mathrm{O}\right)_{5}\left(\mu-\mathrm{H}_{2} \mathrm{O}\right)(\mathrm{OH})_{4}\right] \mathrm{NO}_{3} \cdot 6 \mathrm{H}_{2} \mathrm{O}$.

Table 1

IR frequencies $\left(\mathrm{cm}^{-1}\right)$ and band assignments for $\left[\mathrm{Fe}_{3}\left(\mu-\mathrm{CO}_{3}\right)\left(\mathrm{NH}_{3}\right)(\mu-\mathrm{OH})_{2}\left(\mathrm{H}_{2} \mathrm{O}\right)_{5}\left(\mu-\mathrm{H}_{2} \mathrm{O}\right)(\mathrm{OH})_{4}\right] \mathrm{Cl} \cdot 6 \mathrm{H}_{2} \mathrm{O}(\mathrm{Complex} 1)$, and $\left[\mathrm{Fe}_{3}\left(\mu-\mathrm{CO}_{3}\right)\left(\mathrm{NH}_{3}\right)(\mu-\mathrm{OH})_{2}\left(\mathrm{H}_{2} \mathrm{O}\right)_{5}\left(\mu-\mathrm{H}_{2} \mathrm{O}\right)(\mathrm{OH})_{4}\right] \mathrm{NO}_{3} \cdot 6 \mathrm{H}_{2} \mathrm{O}$ (Complex 2)

\begin{tabular}{|c|c|c|}
\hline \multicolumn{2}{|c|}{ Frequency $\left(\mathrm{cm}^{-1}\right)$} & \multirow{2}{*}{ Assignments } \\
\hline Complex 1 & Complex 2 & \\
\hline 3452 & 3452 & $v(\mathrm{O}-\mathrm{H}) ;(\mathrm{Fe}-\mathrm{OH})$ \\
\hline 3355 & 3354 & $v(\mathrm{O}-\mathrm{H}) ; \mathrm{H}_{2} \mathrm{O}$ \\
\hline 3195 & 3202 & $v(\mathrm{~N}-\mathrm{H}) ; \mathrm{NH}_{3}$ \\
\hline 1635 & 1642 & $\delta\left(\mathrm{H}_{2} \mathrm{O}\right)$ \\
\hline 1567 & 1567 & $\delta\left(\mathrm{NH}_{2}\right) ; \mathrm{NH}_{3}$ \\
\hline 1499 & 1499,1387 & $\begin{array}{l}v(\mathrm{C}-\mathrm{O}) ; \mathrm{CO}_{3}^{2-} \\
v(\mathrm{~N}-\mathrm{O}) ; \mathrm{NO}^{3-}\end{array}$ \\
\hline 1167 & 1152 & $\delta\left(\mathrm{NH}_{2}\right) ; \mathrm{NH}_{3}$ \\
\hline 1031 & 1031 & $v(\mathrm{C}-\mathrm{O}) ; \mathrm{CO}_{3}{ }^{2-}$ \\
\hline 768 & 829 & $\delta\left(\mathrm{CO}_{2}\right) ; \mathrm{CO}_{3}{ }^{2-}$ \\
\hline 632 & 768,631 & $\begin{array}{l}\delta\left(\mathrm{NO}_{2}\right) ; \mathrm{NO}_{3}{ }^{-} \\
\delta\left(\mathrm{CO}_{2}\right) ; \mathrm{CO}_{3}{ }^{2-}\end{array}$ \\
\hline 549 & 549 & $v(\mathrm{Fe}-\mathrm{O})$ \\
\hline 466 & 466 & $v(\mathrm{Fe}-\mathrm{N})$ \\
\hline
\end{tabular}





Fig. 2 - IR spectrum of (a) iron(III) complex 1 in normal and at $200^{\circ} \mathrm{C}$, (b) iron(III) complex 2 in normal and at $200^{\circ} \mathrm{C}$ and (c) iron(III) complexes at $600^{\circ} \mathrm{C}$. 
The thermal decomposition of the $\left[\mathrm{Fe}_{3}\left(\mu-\mathrm{CO}_{3}\right)\right.$ $\left.\left(\mathrm{NH}_{3}\right)(\mu-\mathrm{OH})_{2}\left(\mathrm{H}_{2} \mathrm{O}\right)_{5}\left(\mu-\mathrm{H}_{2} \mathrm{O}\right)(\mathrm{OH})_{4}\right] \mathrm{NO}_{3} \cdot 6 \mathrm{H}_{2} \mathrm{O}$ complex proceeds via four decomposition stages. The first two stages of degradation occur at the maximum temperatures of 52 and $214{ }^{\circ} \mathrm{C}$ and were accompanied by the formation of the $\mathrm{NCO}^{-}$group, which is similar to the related complex $\left[\mathrm{Fe}_{3}(\mu-\right.$ $\left.\left.\mathrm{CO}_{3}\right)\left(\mathrm{NH}_{3}\right)(\mu-\mathrm{OH})_{2}\left(\mathrm{H}_{2} \mathrm{O}\right)_{5}\left(\mu-\mathrm{H}_{2} \mathrm{O}\right)(\mathrm{OH})_{4}\right] \mathrm{Cl} \cdot 6 \mathrm{H}_{2} \mathrm{O}$, and a weight loss of $28.0 \%$ (calc., $27.38 \%$ ) corresponds to the loss of the six uncoordinated $\mathrm{H}_{2} \mathrm{O}$ molecules and $\mathrm{HNO}_{3}$ in the gaseous form. The third step occurs at a maximum temperature of $358{ }^{\circ} \mathrm{C}$ with a weight loss of $17.0 \%$ (calc., $27.29 \%$ ) and was associated with the loss of six $\mathrm{H}_{2} \mathrm{O}$ molecules. The fourth step occurs at a maximum temperature of $549{ }^{\circ} \mathrm{C}$ with a weight loss of $17.00 \%$, which is close to the theoretical weight loss value of $16.97 \%$, and was accompanied by the loss of $\mathrm{HCNO}$ and $3 \frac{1}{2} \mathrm{H}_{2} \mathrm{O}$ molecules. The loss of water molecules at relatively high temperatures may be related to the expected strong $\mathrm{H}$-bonding involving both the $\mathrm{OH}^{-}$and water molecules. According to the above discussion, the decomposition mechanism of the $\left[\mathrm{Fe}_{3}(\mu-\right.$ $\left.\left.\mathrm{CO}_{3}\right)\left(\mathrm{NH}_{3}\right)(\mu-\mathrm{OH})_{2}\left(\mathrm{H}_{2} \mathrm{O}\right)_{5}\left(\mu-\mathrm{H}_{2} \mathrm{O}\right)(\mathrm{OH})_{4}\right]$ $\mathrm{NO}_{3} \cdot 6 \mathrm{H}_{2} \mathrm{O}$ complex is as follows:

$$
\begin{gathered}
{\left[\mathrm{Fe}_{3}\left(\mu-\mathrm{CO}_{3}\right)\left(\mathrm{NH}_{3}\right)(\mu-\mathrm{OH})_{2}\left(\mathrm{H}_{2} \mathrm{O}\right)_{5}\left(\mu-\mathrm{H}_{2} \mathrm{O}\right)(\mathrm{OH})_{4}\right] \mathrm{NO}_{3} \cdot 6 \mathrm{H}_{2} \mathrm{O} \stackrel{52,214^{\circ} \mathrm{C}}{\longrightarrow}} \\
{\left[\mathrm{Fe}_{3}(\mathrm{NCO})\left(\mathrm{H}_{2} \mathrm{O}\right)_{6}(\mathrm{OH})_{8}\right]+6 \mathrm{H}_{2} \mathrm{O}+\mathrm{HNO}_{3}} \\
{\left[\mathrm{Fe}_{3}(\mathrm{NCO})\left(\mathrm{H}_{2} \mathrm{O}\right)_{6}(\mathrm{OH})_{8}\right] \stackrel{358^{\circ} \mathrm{C}}{\longrightarrow}\left[\mathrm{Fe}_{3}(\mathrm{NCO})(\mathrm{OH})_{8}\right]+6 \mathrm{H}_{2} \mathrm{O}}
\end{gathered}
$$

$$
\left[\mathrm{Fe}_{3}(\mathrm{NCO})(\mathrm{OH})_{8}\right] \stackrel{549^{\circ} \mathrm{C}}{\longrightarrow}\left(\mathrm{Fe}_{2} \mathrm{O}_{3}\right)_{1.5}+3 \frac{1}{1} 2 \mathrm{H}_{2} \mathrm{O}+\mathrm{HNCO}
$$

\section{Molar conductance and magnetic moments}

The molar conductance's for the $\left[\mathrm{Fe}_{3}(\mu\right.$ $\left.\left.\mathrm{CO}_{3}\right)\left(\mathrm{NH}_{3}\right)(\mu-\mathrm{OH})_{2}\left(\mathrm{H}_{2} \mathrm{O}\right)_{5}\left(\mu-\mathrm{H}_{2} \mathrm{O}\right)(\mathrm{OH})_{4}\right] \mathrm{Cl} \cdot 6 \mathrm{H}_{2} \mathrm{O}$ and $\left[\mathrm{Fe}_{3}\left(\mu-\mathrm{CO}_{3}\right)\left(\mathrm{NH}_{3}\right)(\mu-\mathrm{OH})_{2}\left(\mathrm{H}_{2} \mathrm{O}\right)_{5}(\mu-\right.$ $\left.\left.\mathrm{H}_{2} \mathrm{O}\right)(\mathrm{OH})_{4}\right] \mathrm{NO}_{3} \cdot 6 \mathrm{H}_{2} \mathrm{O}$ complexes were 71 and 64 $\Omega^{-1} \mathrm{~cm}^{2} \mathrm{~mol}^{-1}$ in DMSO solvent, respectively, indicating their electrolytic nature. ${ }^{37}$ The conductance values revealed the presence of one $\mathrm{Cl}^{-}$or $\mathrm{NO}_{3}{ }^{-}$anion outside the coordination sphere. The effective magnetic moment $\mu_{\text {eff }}$ of the these complexes was between 5.73-5.81 BM, which indicates a high-spin octahedral geometry. ${ }^{38}$

\section{XRD, EDX and SEM studies}

Figure 3 shows the X-ray powder diffraction patterns of the $\mathrm{Fe}_{2} \mathrm{O}_{3}$ product obtained from the thermal decomposition of the $\left[\mathrm{Fe}_{3}\left(\mu-\mathrm{CO}_{3}\right)\left(\mathrm{NH}_{3}\right)(\mu-\right.$ $\left.\mathrm{OH})_{2}\left(\mathrm{H}_{2} \mathrm{O}\right)_{5}\left(\mu-\mathrm{H}_{2} \mathrm{O}\right)(\mathrm{OH})_{4}\right] \mathrm{NO}_{3} \cdot 6 \mathrm{H}_{2} \mathrm{O}$ complex at $600{ }^{\circ} \mathrm{C}$. The diffraction patterns are well indexed and assigned to the hexagonal phase $\alpha-\mathrm{Fe}_{2} \mathrm{O}_{3}$. The $2 \theta$ peaks at $24.08,33.09,35.61,40.83,49.40$, $54.06,57.60,62.25$ and 63.93 can be attributed to the (012), (104), (110), (113), (024), (116), (018), (214) and (300) crystal planes, respectively (Powder Diffraction Standards-JCPDS card No. 80-2377). ${ }^{39}$ The energy dispersive X-ray (EDX) spectrum shows that only $\mathrm{Fe}$ and $\mathrm{O}$ elements are present in the measured $\alpha-\mathrm{Fe}_{2} \mathrm{O}_{3}$ product. This observation is supported by the absence of any XRD pattern other than nanocrystalline $\alpha-\mathrm{Fe}_{2} \mathrm{O}_{3}$. The average particle size of the $\alpha-\mathrm{Fe}_{2} \mathrm{O}_{3}$ NPs was calculated at the highest maximum peak (104) using the Scherrer equation $(1)^{40}$ and was found to be $\sim 14 \mathrm{~nm}$.

$$
\mathrm{D}=(\mathrm{K} \lambda) /(\beta \cos \theta)
$$

where $\theta$ is the Bragg diffraction angle, $\mathrm{K}$ is a constant (0.94 for $\mathrm{Cu}$ grid), $\beta$ is the integral peak width, $\lambda$ is the X-ray wavelength $(1.5406 \AA)$, and $\mathrm{D}$ is the particle size. The scanning electron microscopy (SEM) micrograph of the $\alpha-\mathrm{Fe}_{2} \mathrm{O}_{3} \mathrm{NPs}$ is shown in Figure 4. The SEM micrograph of the $\alpha-\mathrm{Fe}_{2} \mathrm{O}_{3}$ NPs shows a medium degree of agglomeration and particles with a uniform size distribution in the form of flat sheets.

\section{Electronic and optical band gap energy studies}

The electronic spectrum of the $\alpha-\mathrm{Fe}_{2} \mathrm{O}_{3}$ NPs was scanned using a UV-Vis spectrometer and shown in Figure 5. This spectrum shows broad absorption peaks at 299 and $362 \mathrm{~nm}$, which can be attributed to the absorption and scattering of light by the $\alpha-\mathrm{Fe}_{2} \mathrm{O}_{3} \mathrm{NPs}^{41}$. The optical band gap energy $\left(E_{g}\right)$ of the $\alpha-\mathrm{Fe}_{2} \mathrm{O}_{3}$ NPs was estimated from the electronic spectrum using the Tauc relation (equation 2). ${ }^{42}$

$$
\alpha \mathrm{h} v=\mathrm{A}\left(\mathrm{h} v-\mathrm{E}_{\mathrm{g}}\right)^{\mathrm{n}}
$$

where $\mathrm{A}$ is a constant, $\mathrm{h} v$ is the photon energy, $\mathrm{E}_{\mathrm{g}}$ is the energy gap, and $n=1 / 2$ for an allowed direct transition. The band gap energy was determined from the plot of the relationship between $(\alpha h v)^{1 / 2}$ and $\mathrm{hv}$, and the value was $\left(\mathrm{E}_{\mathrm{g}}=2.53 \mathrm{eV}\right)$. This 
value is higher than that of bulk $\mathrm{Fe}_{2} \mathrm{O}_{3}\left(\mathrm{E}_{\mathrm{g}}=2.14\right.$ $2.20 \mathrm{eV}) .{ }^{43}$ Therefore, the increase in the energy band gap compared with that of the bulk material is due to the presence of $\mathrm{Fe}_{2} \mathrm{O}_{3}$ in nano-range. ${ }^{44}$

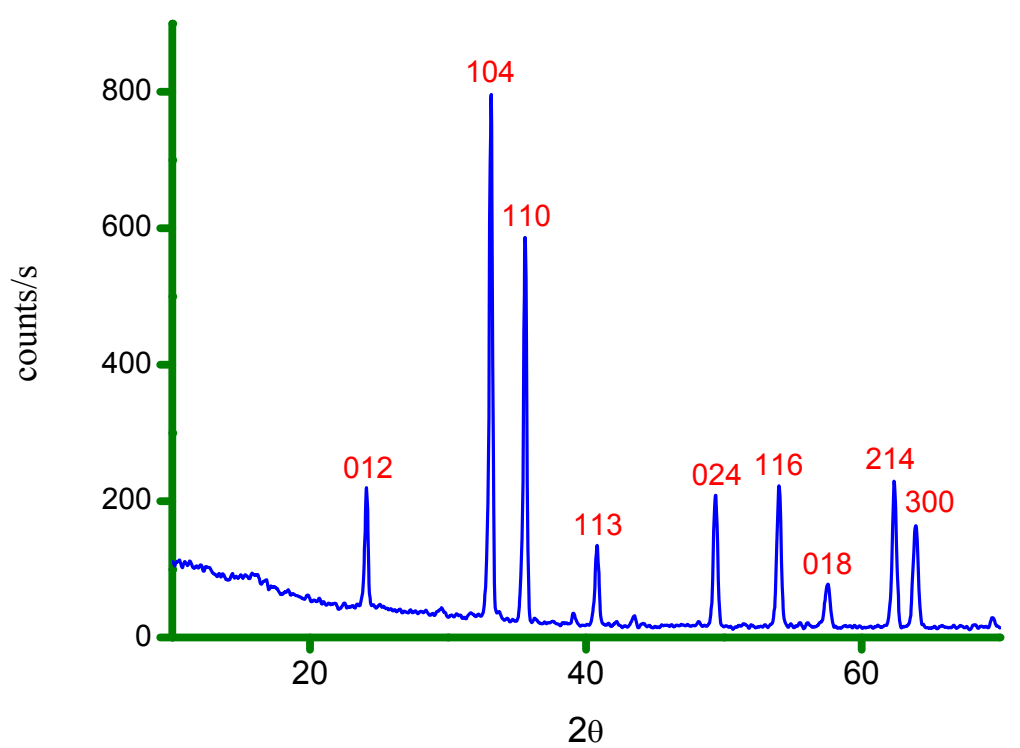

Fig. $3-\mathrm{XRD}$ patterns of the synthesized $\alpha-\mathrm{Fe}_{2} \mathrm{O}_{3} \mathrm{NPs}$.

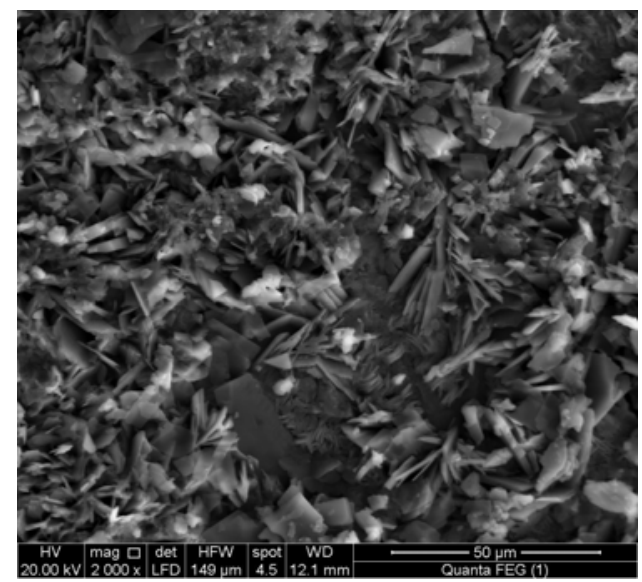

Fig. 4 - SEM micrographs of the synthesized $\alpha-\mathrm{Fe}_{2} \mathrm{O}_{3} \mathrm{NPs}$.



Fig. 5 - UV-Visible spectrum of the synthesized $\alpha-\mathrm{Fe}_{2} \mathrm{O}_{3}$ NPs. 


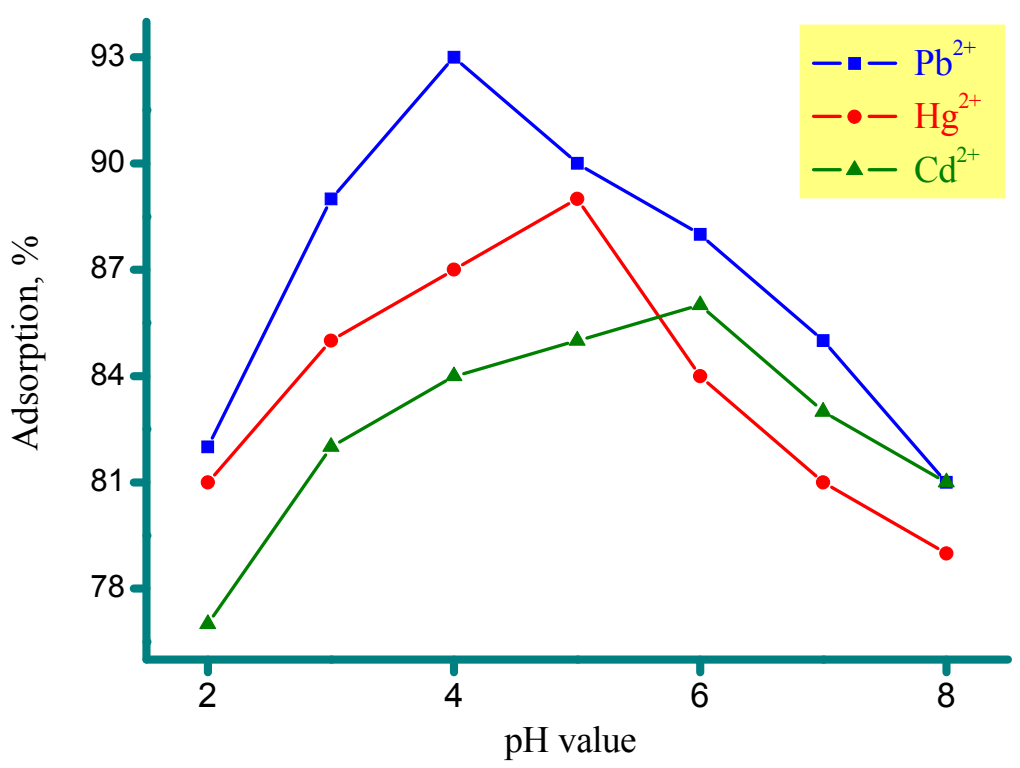

Fig. 6 - Effect of $\mathrm{pH}$ values on the adsorption of $\mathrm{Pb}^{2+}, \mathrm{Hg}^{2+}$ and $\mathrm{Cd}^{2+}$ ions by $\alpha-\mathrm{Fe}_{2} \mathrm{O}_{3} \mathrm{NPs}$.

\section{Factors affecting the removal efficiency of heavy metals}

\section{Effect of the pH}

The influence of the $\mathrm{pH}$ is an important factor in the removal of heavy metal ions using $\mathrm{Fe}_{2} \mathrm{O}_{3}$ NPs. The effect of the $\mathrm{pH}$ on the removal of $\mathrm{Pb}^{2+}$, $\mathrm{Hg}^{2+}$ and $\mathrm{Cd}^{2+}$ ions by $\alpha-\mathrm{Fe}_{2} \mathrm{O}_{3} \mathrm{NPs}$ was examined within the $\mathrm{pH}$ range of $2.00-8.00$, and illustrated in Figure 6. It has been found that approximately 93, 89 and $86 \%$ of the $\mathrm{Pb}^{2+}, \mathrm{Hg}^{2+}$ and $\mathrm{Cd}^{2+}$ ions, respectively, were adsorbed on the $\alpha-\mathrm{Fe}_{2} \mathrm{O}_{3} \mathrm{NPs}$ surface within the $\mathrm{pH}$ range of 2.00-8.00. The removal percentage gradually decreased as the $\mathrm{pH}$ increased. The maximum removals of the $\mathrm{Pb}^{2+}$, $\mathrm{Hg}^{2+}$ and $\mathrm{Cd}^{2+}$ ions were at $\mathrm{pH}$ values of $4.0,5.0$ and 6.0 , respectively.

\section{Effect of the contact time}

The experiments were performed for the adsorption of $20 \mathrm{mg} / 100 \mathrm{~mL}$ of $\mathrm{Pb}^{2+}, \mathrm{Hg}^{2+}$ and $\mathrm{Cd}^{2+}$ ions at $\mathrm{pH}=4.0-6.0$ using an adsorbent dosage of $50 \mathrm{mg}$ of $\alpha-\mathrm{Fe}_{2} \mathrm{O}_{3} \mathrm{NPs}$. The effect of the contact time on the adsorption of these ions by $\alpha$ $\mathrm{Fe}_{2} \mathrm{O}_{3}$ NPs was examined from 10 to $60 \mathrm{~min}$., and represented in Figure 7. It has been found that the adsorption process increased and reached a maximum removal value of $\sim 99 \%$ after 40 min.

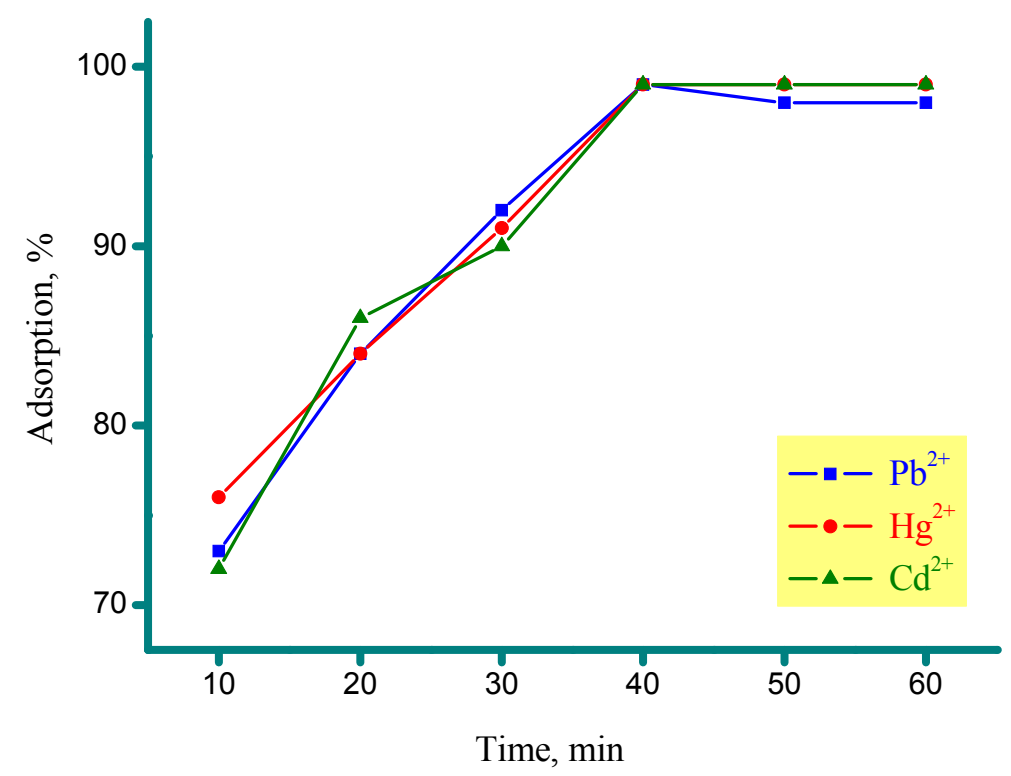

Fig. 7 - Effect of contact time on the adsorption of $\mathrm{Pb}^{2+}, \mathrm{Hg}^{2+}$ and $\mathrm{Cd}^{2+}$ ions by $\alpha-\mathrm{Fe}_{2} \mathrm{O}_{3} \mathrm{NPs}$. 


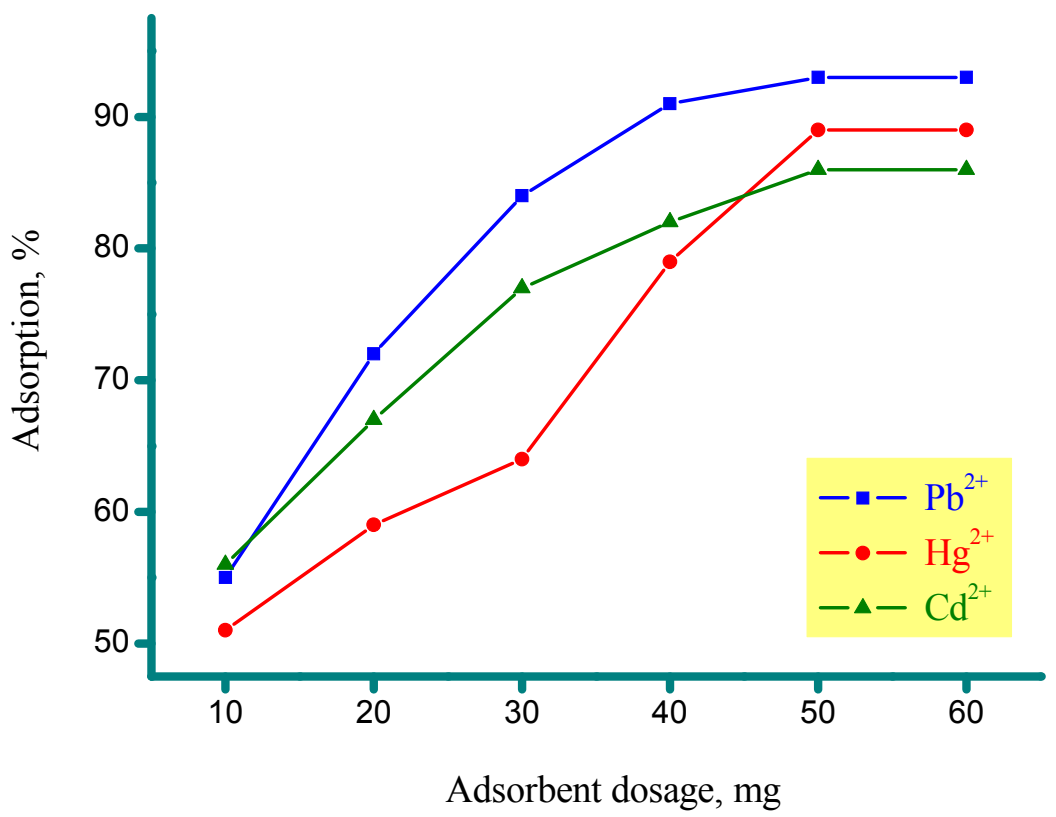

Fig. 8 - Effect of adsorbent dosage of $\alpha-\mathrm{Fe}_{2} \mathrm{O}_{3}$ on the adsorption of $\mathrm{Pb}^{2+}, \mathrm{Hg}^{2+}$ and $\mathrm{Cd}^{2+}$ ions.

Table 2

Electrical conductivity results of iron(III) complexes

\begin{tabular}{l|l|l|l|l|l}
\hline Complexes & $\mathbf{\delta}, \mathbf{o h m}^{\mathbf{1}}$ & $\mathbf{E}_{\mathbf{1}}, \mathbf{e V}$ & $\mathbf{E}_{\mathbf{2}}, \mathbf{e V}$ & $\boldsymbol{n}, \mathbf{c m}^{\mathbf{3}}$ & $\boldsymbol{\mu}, \mathbf{c m}^{\mathbf{2}} / \mathbf{V . s .}$ \\
\hline 1 & $1.92 \mathrm{E}-06$ & 0.49 & 0.29 & $1.45 \mathrm{E} 20$ & $7.98 \mathrm{E}-08$ \\
2 & $1.54 \mathrm{E}-06$ & 0.17 & 0.14 & $1.02 \mathrm{E} 25$ & $2.02 \mathrm{E}-012$ \\
\hline
\end{tabular}

1- $\left[\mathrm{Fe}_{3}\left(\mu-\mathrm{CO}_{3}\right)\left(\mathrm{NH}_{3}\right)(\mu-\mathrm{OH})_{2}\left(\mathrm{H}_{2} \mathrm{O}\right)_{5}\left(\mu-\mathrm{H}_{2} \mathrm{O}\right)(\mathrm{OH})_{4}\right] \mathrm{Cl} \cdot 6 \mathrm{H}_{2} \mathrm{O}$ complex, 2- $\left[\mathrm{Fe}_{3}\left(\mu-\mathrm{CO}_{3}\right)\left(\mathrm{NH}_{3}\right)(\mu-\mathrm{OH})_{2}\left(\mathrm{H}_{2} \mathrm{O}\right)_{5}\left(\mu-\mathrm{H}_{2} \mathrm{O}\right)(\mathrm{OH})_{4}\right] \mathrm{NO}_{3} \cdot 6 \mathrm{H}_{2} \mathrm{O}$ complex.

\section{Effect of the adsorbent dosage}

Figure 8 shows the effect of adsorbent dosage of $\alpha-\mathrm{Fe}_{2} \mathrm{O}_{3}$ NPs on the adsorption of $\mathrm{Pb}^{2+}, \mathrm{Hg}^{2+}$ and $\mathrm{Cd}^{2+}$ ions. It has been found that the removal efficiency of $\mathrm{Pb}^{2+}, \mathrm{Hg}^{2+}$ and $\mathrm{Cd}^{2+}$ ions increased in proportion to the amount of the adsorbent until a certain value was reached. After that, the removal efficiency was constant even if more adsorbent was added. The removal efficiency rapidly increased with the increase in the adsorption of the adsorbent due to the increased availability of absorption sites on the surface area. The experimental study showed that the appropriate dose of $\alpha-\mathrm{Fe}_{2} \mathrm{O}_{3}$ NPs as a good adsorbent for each of the heavy metal ions is $50 \mathrm{mg}$.

\section{Optimum conditions}

The $\alpha-\mathrm{Fe}_{2} \mathrm{O}_{3}$ NPs prepared through the thermal decomposition method showed promising results for the investigated heavy metals in aqueous media. Nearly 93,89 and $86 \%$ removal efficiencies for $\mathrm{Pb}^{2+}, \mathrm{Hg}^{2+}$ and $\mathrm{Cd}^{2+}$ ions, respectively, were achieved using the synthesized $\alpha-\mathrm{Fe}_{2} \mathrm{O}_{3}$ NPs with a low weight of adsorbent ( $50 \mathrm{mg}$ ), short time (40 min.) and at $\mathrm{pH}$ values ranging from 4.0-6.0. The optimum conditions for the efficiency removal of these heavy metals were: an adsorbent dosage of $50 \mathrm{mg}$, a contact time of $40 \mathrm{~min}$., and a $\mathrm{pH}$ of 5.0. The thermal decomposition of the synthesized Feurea complexes produced pure $\alpha-\mathrm{Fe}_{2} \mathrm{O}_{3} \mathrm{NPs}$ in good agreement with the previously results reported $[20-23,25,29]$. The obtained $\alpha-\mathrm{Fe}_{2} \mathrm{O}_{3}$ product was used as adsorbent for water treatment, and the results revealed excellent performance for heavy metal removal in accordance with previously works. ${ }^{25,29}$

\section{Electrical conductivity}

The general equation that used to identify the electrical behavior associated with the movement of electrons can be cited as:

$$
\sigma=q n \mu
$$

where $(\sigma=$ conductivity, $\mathrm{q}=$ charge, $\mathrm{n}=$ concentration, and $\mu=$ mobility of charge carrier). 
The electrical conductivity value was calculated dependent on the following equation:

$$
\sigma=\sigma^{\circ} \exp (-E / K T)
$$

where $\left(\sigma^{\circ}=\right.$ constant and $E=$ activation energy $)$.

The conductivity value increases with the increasing of temperature. So, the solid iron(III) complexes have a semi-conductance behavior. It is found that the conductivity values for $\left[\mathrm{Fe}_{3}(\mu-\right.$ $\left.\left.\mathrm{CO}_{3}\right)\left(\mathrm{NH}_{3}\right)(\mu-\mathrm{OH})_{2}\left(\mathrm{H}_{2} \mathrm{O}\right)_{5}\left(\mu-\mathrm{H}_{2} \mathrm{O}\right)(\mathrm{OH})_{4}\right] \mathrm{Cl} \cdot 6 \mathrm{H}_{2} \mathrm{O}$ and $\quad\left[\mathrm{Fe}_{3}\left(\mu-\mathrm{CO}_{3}\right)\left(\mathrm{NH}_{3}\right)(\mu-\mathrm{OH})_{2}\left(\mathrm{H}_{2} \mathrm{O}\right)_{5}(\mu-\right.$ $\left.\left.\mathrm{H}_{2} \mathrm{O}\right)(\mathrm{OH})_{4}\right] \mathrm{NO}_{3} \cdot 6 \mathrm{H}_{2} \mathrm{O}$ complexes are different dependent on the various of anions outside the coordination sphere. The stability of complexes increased with decreasing the conductivity according to the decreasing in electronic mobility. The electronic conductivity data are listed in Table 2. The conductivity measurement of $\left[\mathrm{Fe}_{3}(\mu-\right.$ $\left.\left.\mathrm{CO}_{3}\right)\left(\mathrm{NH}_{3}\right)(\mu-\mathrm{OH})_{2}\left(\mathrm{H}_{2} \mathrm{O}\right)_{5}\left(\mu-\mathrm{H}_{2} \mathrm{O}\right)(\mathrm{OH})_{4}\right] \mathrm{Cl} \cdot 6 \mathrm{H}_{2} \mathrm{O}$ complex is lesser than $\left[\mathrm{Fe}_{3}\left(\mu-\mathrm{CO}_{3}\right)\left(\mathrm{NH}_{3}\right)(\mu-\right.$ $\left.\mathrm{OH})_{2}\left(\mathrm{H}_{2} \mathrm{O}\right)_{5}\left(\mu-\mathrm{H}_{2} \mathrm{O}\right)(\mathrm{OH})_{4}\right] \mathrm{NO}_{3} \cdot 6 \mathrm{H}_{2} \mathrm{O}$ complex. This result can be assigned to the electronegativity and inductive impact of anions $\left(\mathrm{Cl}^{-} / \mathrm{NO}_{3}{ }^{-}\right)$. The data of mobility for charge carriers was calculated using the following equation:

$$
n=2\left(2 \pi m^{+} K T / h^{2}\right)^{3 / 2} e^{-E / K T}
$$

where $\left(\mathrm{m}^{+}=\right.$effective mass of charge carrier). From Table 2, the mobility results $\mu\left(\mathrm{cm}^{2} / V\right.$.s. $)$ have low data within $\left(10^{-8}-10^{-12}\right)$. These physical data reveal that, the conduction of solid iron(III) complexes occurs by hopping mechanism. The conduction through the localization electrons denote discrete jumps across an energy barrier from one site to other one. It is obvious that the hopping conduction mechanism can be used to described the electrical behavior of the iron(III) complexes.

\section{CONCLUSION}

Two new complexes of iron(III) ions were prepared using urea at $\sim 50{ }^{\circ} \mathrm{C}$. The obtained complexes were characterized using elemental and thermal analyses as well as FT-IR spectroscopy. The two complexes were decomposed at $600{ }^{\circ} \mathrm{C}$ in a static air atmosphere. The XRD and SEM analyses indicated that the decomposition product is $\alpha-\mathrm{Fe}_{2} \mathrm{O}_{3}$ NPs with an average particle size of $\sim 14 \mathrm{~nm}$. The performance and capacity of the $\alpha-\mathrm{Fe}_{2} \mathrm{O}_{3} \mathrm{NPs}$ for the removal of $\mathrm{Cd}^{2+}, \mathrm{Pb}^{2+}$ and $\mathrm{Hg}^{2+}$ ions from wastewater were studied. The optimum $\mathrm{pH}$ value, contact time, and adsorbent dose for the maximum possible removal of these metal ions were investigated. The adsorption capacity of the $\alpha-\mathrm{Fe}_{2} \mathrm{O}_{3}$ NPs for the metal ions was in the following order: $\mathrm{Pb}(\mathrm{II})>\mathrm{Hg}(\mathrm{II})>\mathrm{Cd}(\mathrm{II})$.

Acknowledgements. This work was supported by grants from Vice President for Graduate Study and Research, Taif University, Saudi Arabia under project Grants No. 5558-438-1.

\section{REFERENCES}

1. B. A. Lajayer, M. Ghorbanpour, S. Nikabadi, Ecotox. Environ. Safe., 2017, 145, 377-390.

2. I. A. Aguayo-Villarreal, A. Bonilla-Petriciolet, R. MuñizValencia, J. Mol. Liq., 2017, 230, 686-695

3. H. Xiyili, S. Çetintaş, D. Bingöl, Process Saf. Environ. Protection, 2017, 109, 288-300.

4. J. L.G. Fierro, Metal Oxides: Chemistry and Applications"', CRC Press, Florida, 2006.

5. V. E. Henrich, P. A. Cox, "The Surface Chemistry of Metal Oxides, Cambridge University Press, Cambridge, UK, 1994.

6. C. Noguera, Physics and Chemistry at Oxide Surfaces"', Cambridge University Press, Cambridge, UK, 1996.

7. A. R. José and F.-G. Marcos, "Synthesis, Properties, and Applications of Oxide Nanomaterials", Willey, New Jersey, 2007.

8. J. Hu, M. C. I. Lo and G. Chen, Sep. Purif. Technol., 2007, 56, 249-256.

9. X. Wang, C. Zhao, P. Zhao, P. Dou, Y. Ding and P. Xu, Bioresour. Technol., 2009, 100, 2301-2304.

10. K. L. Palanisamy, V. Devabharathi, N. M. Sundaram, Int. J. Research in Appl., Natural and Social Sci. (IMPACT: IJRANSS), 2013, 1, 15-22.

11. G. Ertl, H. Knozinger and J. Weitkamp, "Handbook of Heterogeneous Catalysis", Wiley-VHC, Weinheim, 1997.

12. J.-P. Jolivet, "Metal Oxide Chemistry and Synthesis: From Solution to Solid State", Wiley, Chichester, 2000.

13. Z. Zheng, "Synthesis and Modifications of Metal Oxide Nanostructures and Their Applications", PhD thesis, School of Physical and Chemical Sciences, Queensland University of Technology, 2009.

14. I. Sheet, A. Kabbani and H. Holail, Energy Procedia, 2014, 50, 130-138.

15. D. Inthorn, Y. Tani, J. Chang, H. Naitou and N. Miyata, J. Environ. Chem. Eng., 2014, 2, 1635-1641.

16. E-B. Son, K-M. Poo, J-S. Chang and K-J. Chae, Sci. Total. Environ., 2018, 615, 161-168.

17. S. Lin, L. Liu, Y. Yang and K. Lin, Appl. Surf. Sci., 2017, 407, 29-35.

18. H. Su, Z. Ye and N. Hmidi, Colloids Surf. A: Physicochem. Eng. Asp., 2017, 522, 161-172.

19. M. Ocana, M. P. Morales and C. J. Serna, J. Colloid Interface Sci., 1998, 212, 317-323.

20. S. Bakardjieva, V. Štengl, J. Šubrt and E. Večerníková, Solid State Sci., 2005, 7, 367-374.

21. S. Asuha, S. Zhao, H.Y. Wu, L. Song and O. Tegus, J. Alloys Compd., 2009, 472, L23-L25.

22. S. Zhao, H.Y. Wu, L. Song, O. Tegus and S. Asuha, J. Mater. Sci., 2009, 44, 926-930.

23. S. Asuha, S. Zhao, X. H. Jin, M. M. Hai and H. P. Bao, Appl. Surface Sci., 2009, 255, 8897-8901. 
24. N. Jović, N. Cvjetićanin, B. Babić-Stojić, D. Makovec and V. Jokanović, Ceram. Int., 2013, 39, 5659-5665.

25. H. Liang, B. Xu and Z. Wang, Mater. Chem. Phys., 2013, 141, 727-734.

26. N. N. Mallikarjuna, A. Venkataraman, Talanta, 2003, 60, 139-147.

27. C. M. Gonzalez, J. Hernandez, J. R. Peralta-Videa, C. E. Botez, J. G. Parsons and J. L. Gardea-Torresdey, J. Hazard. Mater., 2012, 211-212, 138-145.

28. B. Prasad, C. Ghosh, A. Chakraborty, N. Bandyopadhyay and R. K. Ray, Desalination, 2011, 274,105-112.

29. D. Wang, P. Yang and B. Huang, Mater. Res. Bull., 2016, 73, 56-64.

30. P. F. Selwood, "Magnetochemistry", $2^{\text {nd }}$ edition, Wiley (Interscience), N.Y., 1956.

31. K. Nakamoto, "Infrared and Raman Spectra of Inorganic and Coordination Compounds", Wiely, New York, 1978.

32. S. D. Ross, "Inorganic Infrared and Raman Spectra", Mc Graw Hill, London, 1972.

33. M. K. Chaudhuri, S. K. Ghosh, Polyhedron, 1982, 1, 553-555.

34. R. B. Penland, S. Mizushima, C. Curran, J. V. Quagliano, J. Am. Chem. Soc., 1957, 79, 1575-1578.
35. D. Forster, W. D. Harrocks Jr., Inorg. Chem., 1967, 6, 339-343.

36. V. Vogel, "Qualitative Inorganic Analysis", John Wiely \& Sans, Inc. New York, 1987.

37. W. J. Geary, Coord. Chem. Rev., 1971, 7, 81-122.

38. A. D. Kulkarni, S. A. Patil and P. S. Badami, Int. J. Electrochem. Sci., 2009, 4, 717-729.

39. C-Y. Cao, J. Qu, W-S. Yan, J-F. Zhu, Z-Y. Wu and W-G. Song, Langmuir, 2012, 28, 4573-4579.

40. H. P. Klug, (Ed.), "X-ray Diffraction Procedures for Polycrystalline and Amorphous Materials", New York, Wiley, 1974.

41. E. Vélez, G. E. Campillo, G. Morales, C. Hincapié, J. Osorio, O. Arnache, J. I. Uribe and F. Jaramillo, J. Phys.: Conf. Ser., 2016, 687, 012050.

42. J. Tauc, Mater. Res. Bull., 1968, 3, 37-46.

43. B. Gilbert, C. Frandsen, E. R. Maxey and D. M. Sherman, Phys. Rev. B, 2009, 79, 035108.

44. M. P. Dare-Edwards, J. B. Goodenough, A. Hamnett, P. R. Trevell, J. Chem. Soc., Faraday Trans., 1983, 79, 2027-2041. 